\title{
SZABADIDŐ-ELTÖLTÉSI SZOKÁSOK ITTHON ÉS HATÁRON TÚL
}

\author{
Kinczel Antonia
}

\section{Összefoglalás}

Kutatásom célkitüréseinek a megvalósitásához egy online kérdôivet szerkesztettem, mivel a Covid-19 és a folyamatos határzár változások nem tették lehetövé más módszer alkalmazását. Kérdöivemre két országból fogadtam a válaszokat, Magyarországból és Romániából, a magyar nemzetiségú fiatal felnöttektóll (N=323). Célcsoportom a 18-25 év közöotti korosztály volt.

Felmérésemben kitértem a sqabadidö-eltöltési szokásokra, sportmotivációra, a két orsqágban élök közötti különbségekre, illetve hasonlóságokra, ugyanakekor a Covid-19 okozta változásokra is, hiszen érdekesnek találtam megvizsgálni ąt, hogy a járványügyi helyzetben milyen változások követkętek. be. Eredményeim bemutatásáboz. alapstatisztikát és gyakoriságot számitottam, továbbá az összefüggések vizsgálatára chi és páros t próbát használtam. Több hipotézist is felállitottam, amelyek igaznak minösültek.

Eredményeim ąt mutatják, hogy az itthon és a batáron túl élö magyar nemzetiségú fiatal felnöttek egyaránt egyetértenek azzal, hogy a sportnak fontos szerepe van az, egészséges életmódban (átlag=3,72, sd=0,515). Eltérés figyelhetö meg a két országban élök sportolási szokásaiban és sportmotivációjában. A Magyarországon élók egy béten több órát sportolnak (átlag=4,437, sd=2,8175), mint a Romániában élók (átlag=3,678, sd=2,4143) és elégedetebbek a sportolási helyszinekekel és lehetöségekelel. A motivációs tényezök közül a sport szeretete, a közösséghez tartozás sokekal nagyobb értékelést kapott a magyarországi válaszadóknál. A Covid-19 hatására a sportolási alkalmak száma csökekent ( $t=4,026, p=0,000)$, így nem meglepö, hogy a sportolással töltött órák száma is csökkent $(t=4,598, p=0,000)$. Észrevehetö módosulás következett be a sportolási helyszineknél, továbbá a szabadidós tevékenységeknél is. Az emberek többsége kevés idót szán a sportolásra és az aktiv szabadidó-eltöltésre, amit a Covid-19 csak nagyban felerösitett, ezért nagyon fontos a sportnak és az aktiv szabadidö-eltöltési tevékenységeknek a számos pozitiv hatását tudatositani az emberekben, továbbá felmérni a motivációs tényezóket, elégedettségi szintet, hogy egy minél egészségesebb, aktivabb, kiegyensúlyozottabb életet éljünk.

Kulcsszavak: sqabadidö-eltöltés, Covid-19, motiváció, sport

JEL: Z2 


\title{
LEISURE HABITS IN HUNGARY AND ABROAD
}

\begin{abstract}
Absrtact
In order for me to achieve the goals of my research, an online survey was compiled, as the difficulties and the constant changes in border closure-status did not give space for any other methods. Responds to my survey arrived both from Hungarian and Romanian young adults ( $N=323$ of 18-25 year-olds).

In my research, leisure habits, sports motivation, differences and similarities between the two countries were analysed, with the changes caused by Covid-19 as well, as I find it interesting to examine what changes have taken place in this epidemiological situation. Besides the basic statistics and frequency calculated, in order to examine correlations of the data Chi2 and paired t-test were used. Several of the bypotheses set up were considered true.

The results show that young adults of Hungarian nationality living both in Hungary and outside of the border agree that sport plays an important role in a healthy lifestyle (average $=3.72, s d=0.515$ ). There is a difference however in the sports habits and sports motivation of those living in Hungary and of the Hungarians living outside of the border. In the case of the former, it became apparent, that they play sports and exercise more on a weekly basis (average $=4.437, s d=2.8175$ ) than those living in Romania (average $=3.678, s d=2.4143$ ) and are more satisfied with sports venues and opportunities. In terms of motivations, among domestic respondents, the love of sport and belonging to a community played a much prominent role. As Covid-19 reduced the number of sports events and opportunities $(t=4.026, p=0.000)$, it is not surprising that the number of hours spent playing sports and exercising decreased as well $(t=4.598, p=0.000)$. Moreover, there has been a noticeable change in sports venues as well as leisure activities. Most people already spend little time on sports and physical activities, which Covid-19 has only greatly decreased, so it became very important to make people aware of the many positive effects of sports and active leisure time spending, as well as to assess motivational factors and satisfaction levels, in order to live a healthier, more active, more balanced life.
\end{abstract}

Keywords: leisure time spending, Covid-19, motivation, sport

JEL:Z2 


\section{Bevezetés}

A sport és a mozgás gyermekkorunk óta ismert fogalmak, azonban az életkor előrehaladtával egyre kevesebb idôt szánunk rá (Simon et al. 2018). A mai modern, felgyorsult, időhiányos, munka és teljesítményelvű világunkban a sportnak és az aktív szabadidő-eltöltésnek nagyon fontos szerepe van, hiszen az inaktivitásunk és az azokból kifolyó betegségek aránya egyre nô. A sportnak számos pozitív hatása van az emberek életére (Müller - Bácsné, 2018; Lenéné et al. 2018; Dobay et al. 2017; Bendíková et al. 2018, Váczi, 2015), továbbá az egészséget támogató és védő, prevenciós eszköz (Gabnai et al. 2019; Bíró, 2018; Lenténé et al. 2019; Molnár, 2019; Fehér et al. 2019; Boda et al. 2019), ugyanakkor egy nagyszerű kikapcsolódási, feltöltődési, önbizalomerősítő, közérzetjavító program is. Napjainkban egyre nagyobb hangsúlyban azok a rekreációs tevékenységek is előtérbe kerülnek, melyek a lelki egészséget, a stressz-oldást és a jó-közérzet kialakítását célozzák meg (Lengyel, 2019; Müller et al. 2013; Müller et al. 2009; Bíró - Müller, 2017). Különösen fontos ez a határmenti térségekben (Dávid et al. 2007, 2008). A kutatások arra is rávilágítanak, hogy a családnak meghatározó szerepe van az egészséges életmódelemek kialakításában és megszilárdításában (Laoes et al. 2020a, b; Laoues et al. 2019; Müller et al. 2019b; Kós - Herpainé, 2019). Emellett fontos szerepet játszik a biztonság is (Bujdosó - Györki, 2008).

A Covid-19 hatására az ülő, mozgásszegény életmódunk csak megerősödött, hiszen még kevesebb lehetőségünk volt a mozgásra, kevesebbet sétáltunk, nem hagytuk el olyan gyakran az otthonunkat és nagyon sokan áttértek az otthoni munkavégzésre és a diákok is az online oktatásra. A szabadidejükben az emberek a legtöbb idejüket a televízióra és filmnézésre, valamint internetes játékokra és zenehallgatásra fordították ebben a helyzetben, melyhez hozzájárult a digitalizáció fejlődése is (Murtaza et al. 2021.). A karanténban az átlagosan több mint 3 órát filmnézéssel töltők aránya 3,4\%-ról 9,4\%-ra emelkedett. Az interneten töltött idő (játékra, zenehallgatásra, hírolvasásra) szintén növekedett 9,2\%-ról 12,3\%-ra (Gősi - Magyar, 2020). Elmondható, hogy a járványügyi helyzet lelassította életmódunkat, azonban olyan tevékenységekre fordítottunk fennmaradó időnket, amelyek nem segítették elő az egészségesebb életmódunkat.

Ahhoz, hogy ebben a jelenlegi életünkben egy egészséges, kiegyensúlyozott, aktív, kevésbé stresszes életet éljünk, elengedhetetlen a testmozgás és az aktív rekreációs tevékenységek előtérbe kerülése, hiszen a legfrissebb tanulmányok a magyarok körében igen magas elhízás mértékéről számolnak be (Bácsné et al. 2020). Fontos, hogy felismerjük a szabadidősportnak és az aktív rekreációs tevékenységeknek a pozitív hatását és hogy beépítsük az elengedhetetlen mindennapi mozgást az életünkbe. 


\section{Anyag és módszer}

Kutatásom témája a Magyarországon és Romániában élő magyar nemzetiségű fiatal felnőttek szabadidő-eltöltési szokásainak vizsgálata, kitérve a motivációs tényezőkre, az elégedettségi szintre továbbá a Covid-19 okozta változásokra. Célom e témák feltérképezése, ugyanakkor az itthon és határon túl élő magyar nemzetiségû válaszadók közötti eltérések és hasonlóságok bemutatása.

Célkitűzéseimmel összhangban több hipotézist is megfogalmaztam: H1: A Magyarországon élők több időt szánnak a sportolásra és elégedettebbek a sportolási helyszínekkel. H2: A Covid-19 hatására a sportolással töltött idő mértéke csökkent és nőtt a passzív szabadidős tevékenységekre fordított idő. H3: A pandémia hatására megváltoztak a sportolási helyszínek.

Vizsgálatomban egyaránt alkalmaztam primer és szekunder kutatást is. Primer kutatásomhoz az online kérdőívezés módszerét választottam, hiszen ez bizonyult a legalkalmasabb módszernek ahhoz, hogy mindkét országból tudjak fogadni válaszokat a járványügyi helyzetben. Célcsoportom a 18-25 év közötti, magyar nemzetiségű fiatal felnőtt korosztály volt, akik Magyarország vagy Románia területén élnek. Magyarország Észak-alföldi régiójából, Románia Észak-Nyugati térségéből érkeztek a válaszok, amelyek egymás szomszédjai $(\mathrm{N}=323)$. Eredményeim bemutatásánál alapstatisztikát és gyakoriságot számítottam, továbbá a két országból érkezők válaszainak összehasonlításához és a Covid-19 okozta változások elemzéséhez chi ${ }^{2}$ és páros t próbát használtam. Szekunder kutatásom megfelelő volt arra, hogy saját eredményeimet összehasonlítsam más hazai és nemzetközi kutatások eredményeivel.

Fontosnak tartom már az elején kiemelni, hogy kutatásom időszakában egyik országban sem voltak korlátozások, nem voltak zárva a fitnesztermek, nyugodtan lehetett sportolni, így eredményeimet ezek nem tudták befolyásolni.

\section{A minta bemutatása}

A vizsgálatom 323 fö, két országban élő fiatal felnőtt válaszait dolgozza fel és elemzi. Határon belülrôl és túlról is szép számban érkeztek válaszok, kis eltéréssel, amelyek lehetôvé teszik a válaszok összehasonlítását. A Magyarországon élő kitöltők aránya 55,7\% (180fö), míg a Romániában élőké 44,3\% (143 fö). A válaszadók 58,2\%-a nő (188fó) és 45,2\%-a férfi (135 fö). Mindkét országban az elemzéshez megfelelő arányban töltötték ki a nők és férfiak a kérdőívet, a női kitöltők 54,8\%-a (103 fö), a férfiak 57,0\% (77 fö) Magyarországon, a nők 45,2\%-a (85 fö), a férfiak 43,0\% (58 fö) pedig Romániában él.

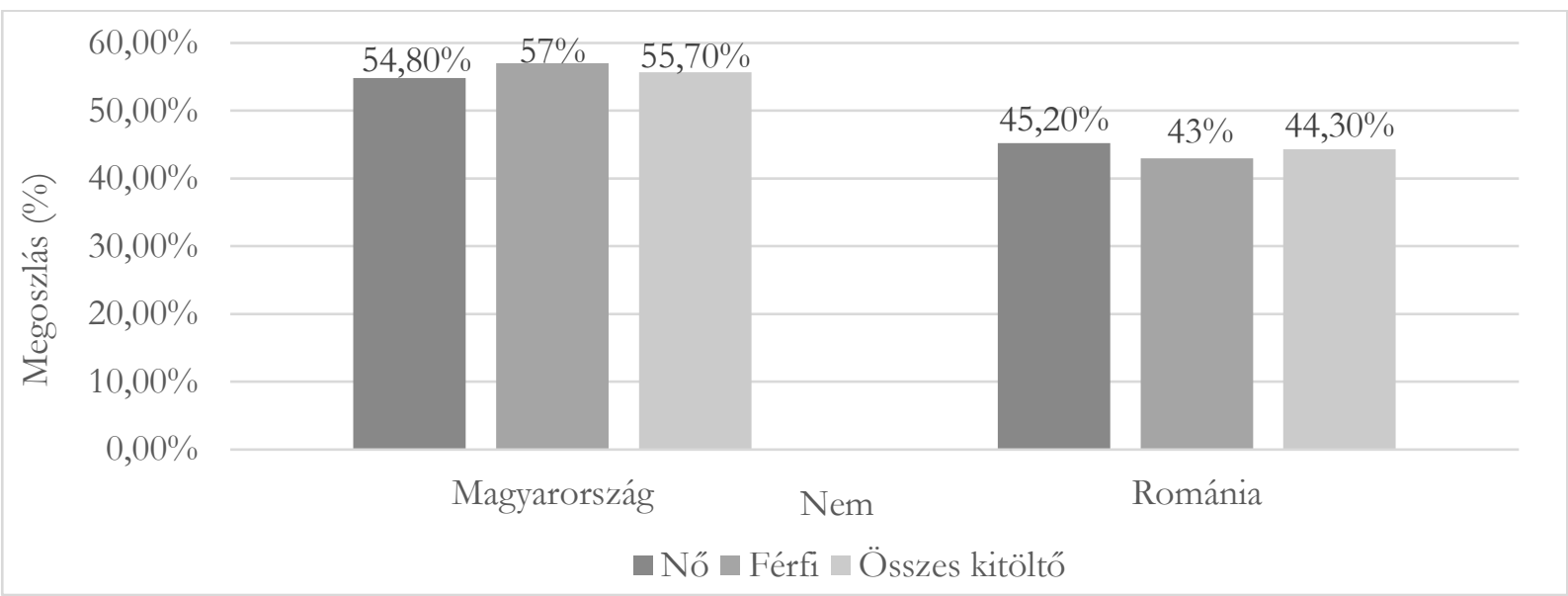

1. ábra. A válaszadók életkor szerinti megoszlása

Forrás: Saját forrás, 2020 
Célcsoportom életkorához megfelelően válaszadóim 91\%-a (294 fő) tanuló vagy ülő munkát végez. Vegyes munkát végeznek (ülő és fizikai munkát is) a kitöltők 5,3\%-a (17 fó), akik pedig csak fizikai munkát azok aránya 3,7\% (12 fő).

A vizsgált személyek többsége, 53,9\%-uk (174 fö) városban, 24,1\%-uk (78 fő) faluban, 18,3\%uk (59 fö) megyeszékhelyen és 3,7\%-uk (12 fő) pedig fővárosban él.

Kutatásomban nagy hangsúlyt fektettem az aktív szabadidôs tevékenységekre és a szabadidősportra, ezért rákérdeztem válaszadóimnál, hogy szerintük a sportnak mennyire van fontos szerepe az egészséges életmód kialakításában és fenntartásában. A válaszokat egy 1-4-es skálán fogadtam, ahol az 1-nincs fontos szerepe, 4-nagyon fontos szerepe van jelentette. A kitöltôk 74,9\%-a (242 fö) a 4-es, 22,0\%-a a 3-ast, 3,1\%-a pedig a 2-es értékelést adta (átlag=3,72, sd=0,515). Elmondható, hogy a Magyarországon és a Romániában élő magyar nemzetiségű fiatal felnőttek hasonlóan vélekednek e kérdés terén, hiszen a magyarországi kitöltők 78,3\%-a (átlag=3,77, $\mathrm{sd}=0,462)$, a romániai kitöltők 70,6\%-a (átlag=3,66, sd=0,570) adta a 4-es értékelést.

\section{Eredmények}

Láthatjuk a fent említett eredményekből is, hogy az emberek tisztában vannak a sport főbb pozitív hatásaival és tudják azt, hogy a sportnak kiemelkedően fontos szerepe van abban, hogy egy egészséges életet éljünk. Kíváncsian vártam annak eredményeit, hogyha az emberek tisztában vannak ezekkel a tényekkel, akkor ők mennyi időt szánnak a sportolásra. Válaszadóim 11,8\%-a (38 fö) 1-2 órát, 30,7\%-a (99 fö) 2-3 órát, 23,2\%-a (75 fö) 3-5 órát, 18,6\%-a (60 fö) 5-8 órát, 7,7\%-a (25 fö) 8-10 órát, 8,0\%-a (26 fö) több, mint 10 órát szán egy héten a sportolásra. Ha külön lebontjuk az eredményeket a Magyarországon és Romániában élő válaszadóim szerint, akkor különbséget lehet felfedezni. A magyarországi fiatal felnőttek egy héten több órát sportolnak (átlag=4,437, $\mathrm{sd}=2,8175)$ szemben a Romániában élőkkel (átlag=3,678, sd=2,4143). Szintén megfigyelhetó különbség, hogy míg a Magyarországon élő válaszadóim 42,2\%-a (76 fö) már 5-8, 8-10 és több, mint 10 órát is rászánnak a sportolásra, a romániai kitöltőim csak 24,5\%-a (35 fô) sportol ennyi órát egy héten. Azonban Romániában magasabb az 1-2, 2-3, 3 -5 óra sportolásnak az aránya 75,6\% (108 fö), míg Magyarországon ez az adat 57,8\% (104 fö).

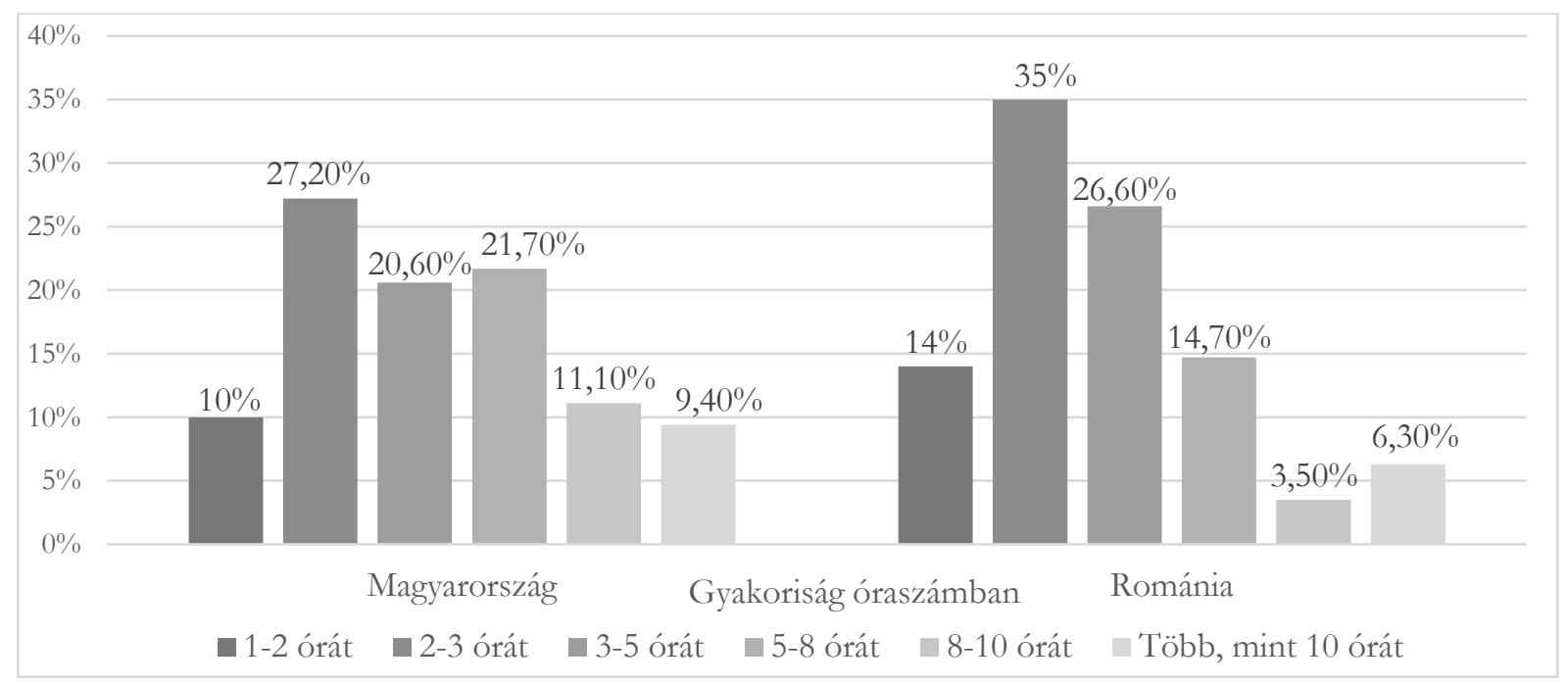

2. ábra. Sportolással töltött órák száma egy héten

Forrás: Saját forrás, 2020 
Mint mindenhez, így ahhoz, hogy elkezdjünk sportolni, motivációra van szükségünk. A megkérdezettek egy 1-5-ös skálán értékelhették azt, hogy az általam megadott tényezők mennyire motiválják őket a sportolásra. A legnagyobb motivációs tényező válaszadóim számára az egészség (átlag=4,03, sd=0,981). Szintén magas értékelést kapott a kinézet (átlag=3,82, sd=1,138), a fejlődésvágy (átlag=3,78, sd=1,134), a sport szeretete (átlag=3,64, sd=1,185). A közösséghez tartozás kevésbé motiváló tényező kitöltőim számára (átlag=2,80, sd=1,323).

A két országban élők között eltérés figyelhető meg a motivációs tényezőkben. A sport szeretete nagyobb ösztönző szerepet kap a Magyarországon élőknél, mivel 66,1\%-uk (119fö) a 4-es vagy 5ös értékelést választotta, szemben a Romániában élő fiatal felnőtt válaszadóinkkal, ahol ugyanezeket az értékeléseket 49,1\%- uk (71 fö) választotta (chi2=13,033, p=0,011). Az egészség és a kinézet mindkét országban magas értékelést kapott. A közösséghez tartozásnál szintén különbség fedezhető fel, mivel a magyarországi kitöltők 42,3\%-a (76 fö) adta a 4-es vagy 5-ös értékelést e inspiráló tényezőre, míg a romániai kitöltők közül csak 16,1\% (23fö) ( $\mathrm{p}=0,000$, chi2=32,127). A fejlődésvágy szintén nagyobb serkentő tényező a magyarországi válaszadóknál, mivel 72,3\%-uk (130 fö) adta a 4-es vagy 5-ös értékelést, ellentétben a romániai válaszadóknál, ahol csak 54,6\%-uk válaszolta ugyan azt $(\mathrm{p}=0,000$, chi2 $=32,310)$.

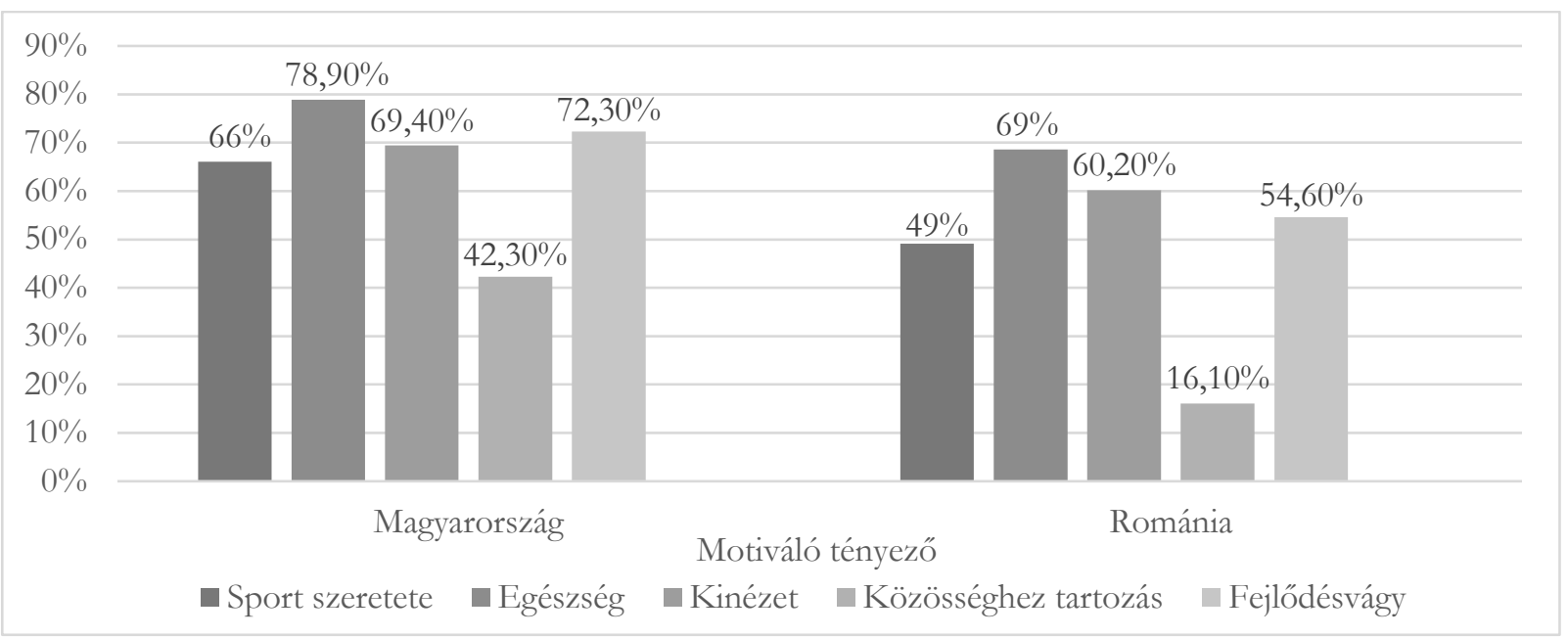

3. ábra. Motivációs tényezők

Forrás: Saját forrás, 2020

Kutatásomban vizsgáltam azt is, hogy a válaszadóim mennyire vannak megelégedve a sportolási helyszínekkel és lehetőségekkel. A határon belül élők 76,7\%-a (138 fő), a határon túl élők 48,3\%uk (69 fö) van megelégedve a sportolási helyszínekkel a lakóhelyén (chi2 $=27,956, \mathrm{df}=1, \mathrm{p}=0,000$ ). E eredményem összhangban van Fenyves és munkatársai eredményeivel, mely szerint Romániában kevesebb a sportolási helyszín és lehetőség (Fenyves et al., 2019b). Érdekesnek találtam külön kitérni arra a kérdésre is, hogy válaszadóim mennyire vannak megelégedve a sportolási lehetőségekkel az iskolákban. Magas eltérés figyelhető meg a két országban élők válaszai alapján (chi2=44,663, df=1, p=0,000). A Magyarországon élő válaszadók 59,4\%-a (107fö), a Romániában élők közül csak 22,4\%-a (32 fö) van megelégedve a sportolási lehetôségekkel. Romániában kevesebb a testnevelés óraszáma is az intézményekben, ami valószínúleg hozzájárult ahhoz, hogy a megkérdezettek 77,6\%-a (143 fó) szerint nem fektetnek elég hangsúlyt a sportra az iskolákban.

Eredményeim alátámasztják első hipotézisem, mely szerint a Magyarországon élők több időt szánnak a sportolásra és elégedettebbek a sportolási helyszínekkel.

A Covid-19 megjelenése számos változást eredményezett életünkben és a fizikai aktivitásban is, melyet több nemzetközi kutatás is megerősít (Lesser - Nienhuis, 2020; Chen et al., 2020; Spence et al., 2021). Ahogyan más szakirodalmak is bebizonyították előtérbe kerültek az olyan 
tevékenységek amelyekhez nem tartozik fizikai aktivitás és a sport, mozgás háttérbe szorult. A járványügyi helyzet megjelenése előtt a felmért minta átlag=3,33 (sd=1,563) alkalommal sportolt, mely a járványügyi helyzetre átlag $=3,01(\mathrm{sd}=1,554)$ alkalomra csökkent $(\mathrm{t}=4,026, \mathrm{p}=0,000)$. A pandémia elôtt válaszadóim közül mindenki eljárt sportolni, azonban ebben a helyzetben 1,4\%-uk (4 fö) már egyszersem ment el sportolni. Ebben az időszakban megemelkedett a heti egy, illetve két sportolással eltöltött alkalomszám, ugyanakkor csökkent a három, négy, öt, hat alkalomszám és teljesen eltűnt a heti hét, tíz sportolási alkalom.

A Covid-19 előtti sportolási alkalmak számában a két ország válaszadói között nem fedezhető fel nagy különbség, azonban a járványügyi helyzetben ez az eltérés már számottevô. A Romániában élők kevesebbszer mentek el sportolni, mint a magyarországi lakosok (chi2=14,118, df=7, $\mathrm{p}=0,033)$.

Nem meglepő tény, hogyha csökkent a sportolással töltött alkalmak száma, akkor a sportolással töltött órák számában is csökkenés figyelhető meg. A járványügyi helyzet előtt az átlag 4,101 (sd=2,6694) szemben a járványügyi helyzetben, ahol az átlag lecsökkent 3,624-re (sd=2,3935), mely különbséget a t próba is igazolt $(\mathrm{t}=4,598, \mathrm{p}=0,000)$.

Pár szabadidős tevékenység változásának vizsgálatára is kitértem kutatásom során. A passzív pihenéssel, lustálkodással $(\mathrm{t}=-4,055, \mathrm{p}=0,000)$, internetezéssel, playstationnal, online játékokkal $(\mathrm{t}=-2,624, \mathrm{p}=0,009)$ olvasással, tanulással és home office-al $(\mathrm{t}=-2,555, \mathrm{p}=0,011)$ töltött idő növekedése figyelhető meg a pandémiában, amelyekhez ugyebár nem tartozik fizikai aktivitás, ezzel is növelve inaktivitásunkat. A mozgással járó tevékenységek, mint például a bulikba, színházba, társas összejövetelekre való kimozdulás csökkent $(\mathrm{t}=13,945, \mathrm{p}=0,000)$. Eredményeim felhívják a figyelmünket arra, hogy a Covid-19 hatására még inaktivabbakká váltunk.

A második hipotézisem is igaznak minősül, hiszen láthatjuk, hogy a Covid-19 hatására a sportolással töltött idő mértéke csökkent és nőtt a passzív szabadidős tevékenységekre fordított idő.

A sportolási helyszínek kiválaszátásban is differencia figyelhető meg. A járványügyi helyzetben a fittnes-welness központban történő edzés 38,40\%-ról (124 fö) 15,50\%-ra csökkent (50 fö) (22,9\%), míg az otthon végzett sportolás 18,90\%-ról (61fő) 49,50\%-ra (160 fö) növekedett $(+30,6 \%)$. A szabadban, sportpályán végzett edzések száma is csökkent 42,70\%-ról (138 fó) 35,00\%-ra (113 fó) (-7,7\%). A kutatásom időszakában nem voltak korlátozva a sportolási helyszínek, azonban láthatjuk, hogy az emberek mégis inkább a biztonságosabb helyszínt választották.

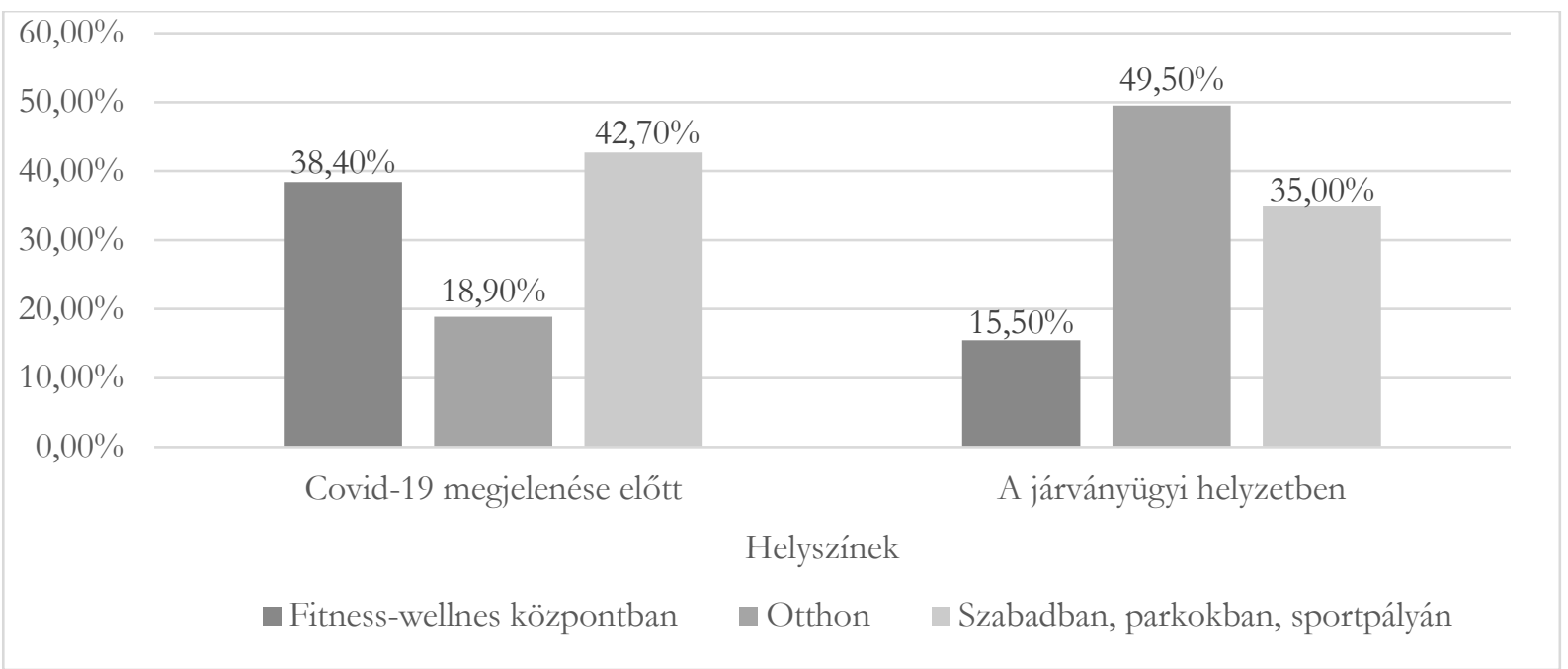

\section{4. ábra. Sportolási helyszínek}

Forrás: Saját forrás, 2020 
Harmadik hipotézisem is teljesült, hiszen a pandémia hatására az emebrek már más sportolási helyszíneket választottak.

Eredményeim kimutatták azt, hogy a határon belül és túl élő válaszadóim a sportolás tekintetében inkább inaktívnak bizonyulnak, így fontos lenne, hogy a sportolási gyakoriságot és sportra fordított időt, valamint annak intenzitását növelni tudjuk, mely a WHO szerint is további egészségügyi előnyt eredményezhet.

\section{Köveztetések és javaslatok}

Mint láthatjuk kutatásom eredményeiből, a koronavírus hatása tehát nemcsak a gazdasági de a társadalmi életre is igen nagy hatást gyakorlott a korlátozó intézkedésekkel, a távolságtartással és a járványügyi szabályozásokkal. Számos szakirodalom foglalkozik Magyarországon de külföldön is a járvány hatásaival és következményeivel a különböző területekre fókuszálva (Poór et al. 2021; Schuchat, 2020; Hossain, 2021).

A Covid-19 hatására a szabadidős tevékenységekben a társas tevékenységek háttérbe szorultak, a szabadidősport területén is az egyénileg űzhető, biztonságos sportolási környezet preferenciája (otthon, szabadtéren) figyelhetô meg. Szintén jól látható, hogy a járványügyi helyzet hatása volt az is, hogy a bezártságból fakadó inaktivitás magasan megemelkedett. Ez megváltoztatta az emberek testi és lelki jólétét is, mely új kihívásokat jelent a szabadidősport számára is, ami a meglévő trendeken kívül (Müller et al. 2019a) új fogyasztói szokásokat is eredményezett ezen a területen. Megjelentek az online edzések, mely trend az első helyre került 2021-ben.

$\mathrm{E}$ adatokat figyelembe véve, elmondható, hogy egy ilyen idôszakban még fontosabb lenne az aktivitással töltött idő növelése, amelyet ebben a helyzetben online térben vagy a média segítségével tudnánk megvalósítani, mint például online edzések ingyenes elérése, sportcsatornákon élő edzések közvetítése, sétára, házimunkára való felhívó üzenetek megjelenése stb. Az átalakult munkavégzés és a korlátozások miatt az EMMI (2020) is ajánlást fogalmazott meg, amely kiemeli többek között a rendszeres fizikai aktivitás fontosságát ezen időszak alatt. Szintén fontos, hogy a lelki egészségünk megőrzésére is odafigyeljünk, amelyet logikai feladványok, művészet és intellektuális játékok segíthetnek (Szalay, 2020).

A Covid-19, mint ahogyan kutatásom eredményei bebizonyítják nem serkentettek minket egy egészségesebb életmód kialakításához. Fontos kiemelni, hogy sajnos a járványügyi helyzet előtt is mindkét ország inkatívnak tekinthető a sportolás tekintetében, hiszen az Európai Bizottság 2017. évi decemberi felméréséből kiderült, hogy az Unióban a megkérdezettek 46\%-a nem sportol, azonban ez az arány Magyarországon 53\%, míg Romániában 10\%-al nagyobb, 63\%. Lényeges figyelembe vennünk kutatásom adatait, melyek rávilágítanak arra, hogy szükség lenne több sportolási lehetôség biztosítása, sportolási programok szervezése, sportolási helyszínek építése, fejlesztése. Kulcsponti tényező, hogy felmérjük az emberek igényeit, rájöjjünk arra, hogy mi gátolja őket az aktívabb életmód folyatásához és hogy e problémákra megoldásokat találjunk.

Jelenlegi túlhajszolt, elkényelmesedett, inkatívnak mondható életünkben létfontosságú elem kellene, hogy legyen a testmozgás, az aktív rekrációs tevékenységek, melynek ösztönzését már ösztönzését már több szerző is kiemelte (Hidvégi et al. 2017), hiszen a sportnak számos pozitív hatása van.

\section{Köszönetnyilvánítás}

Az Innovációs és Technológiai Minisztérium ÚNKP-20-1 kódszámú Új Nemzeti Kiválóság Programjának a Nemzeti Kutatási, Fejlesztési és Innovációs Alapból finanszírozott szakmai támogatásával készült. 


\section{Hivatkozott források}

[1.] Bácsné Bába É. - Ráthonyi G. - Müller A. - Ráthonyi-Odor K. - Balogh P. - Ádány R. Bács Z. (2020): Physical Activity of the Population of the Most Obese Country in Europe, Hungary. Frontiers in Public Health, 8, 1-8. DOI: 10.3389/fpubh.2020.00203

[2.] Bendíková E. - Marko M. - Müller A. - Bába É. Bácsné (2018): Effect of Applied HealthOriented Exercises in Physical and Sport Education on Musculoskeletal System of Female Students. Acta Facultatis Educationis Physicae Universitatis Comenianae, 58(2),84-96. DOI: 10.2478/afepuc-2018-0008

[3.] Bíró M. - Müller A. (2017): Aktív pihenés, rekreáció = Active relaxation, recreation. In: Dobos, Anna; Mika, János (szerk.): Természeti és kultuirtörténeti értékeke Eger térségében = Natural and cultural heritage in the Eger Region. Eger: Líceum Kiadó, pp. 128-130.

[4.] Bíró M. (2018): Bevezetés a sportpedagógiába In: Münnich, Ákos (szerk.) Fejezetete a Sportpszichodiagnosztika és Tanácsadás témaköreiböl. Debrecen: Debreceni Egyetem Bölcsészettudományi Kar Pszichológiai Intézet. Letöltés dátuma: 2021.05.10. forrás: http://psycho.unideb.hu/sport/fejezetek/bm sportpedagogia/ book/index.html

[5.] Boda E. J. - Bácsné, Bába É. - Laoues-Czimbalmos N. - Müller A. (2019): Rekreációs fogyasztói szokások vizsgálata magyar fiatal felnőttek körében. Különleges Bánásmód, 5(4),3344. DOI: $\underline{10.18458 / K B .2019 .4 .33}$

[6.] Bujdosó Z. - Györki M. (2011): A biztonság szerepe a turizmusfejlesztésben. Acta Carolus Robertus, 1(2), 45-55.

[7.] Chen P. - Mao L. - Nassis G. P. - Harmer P. - Ainsworth B. E. - Li F. (2020): Coronavirus disease (2019-nCoV): The need to maintain regular physical activity while taking precautions. Journal of sport and health science, 9(2), 103-104. DOI: 10.1016/i.jshs.2020.02.001

[8.] Dávid, L. - Tóth, G. - Bujdosó, Z. - Herneczky, A. (2007): A turizmus és a regionális versenyképesség kapcsolatának mutatói a Mátravidék példáján keresztül. Észak-magyarországi stratégiai füretek, 4(1), 3-20.

[9.] Dávid L. -Bujdosó Z. - Tóth G. (2008): Tourism planning in the Hajdú-Bihar - Bihor Euroregion In: Süli-Zakar, I (szerk.): Neighbours and partners: on the two sides of the border. Debrecen: Kossuth Egyetemi Kiadó, pp. 323-332.

[10.] Dobay B. - Müller A. - Bendíková E. (2017): Adult Health in Terms of Selected Lifestyle Factor. Disputationes Scientificae Universitatis Chatholicae In Ruzomberok, 17(4), 32-39.

[11.] Fehér A. - Bácsné, B. É. - Müller, A. - Szakály, Z. (2019): MPAM-R modellekkel kapcsolatos kutatások rendszerezése - Szakirodalmi áttekintés. In: Fehér A. - Szakály Z.: Egészségpiaci kutatások. Debrecen: Debreceni Egyetem Gazdaságtudományi Kar, pp. 173-183.

[12.] Fenyves V. - Dajnoki K. - Bácsné Bába É. (2019b): Sportolási szokások vizsgálata a Campus Sportfesztivál tapasztalatai alapján. Acta Carolus Robertus, 9(2), pp. 27-40. DOI: 10.33032/acr.2019.9.2.27

[13.] Gabnai Z. - Müller A. - Bács Z. - Bácsné Bába É. (2019): A fizikai inaktivitás nemzetgazdasági terhei. Egészségfejlesztés, 60(1), 20-30. DOI: 10.24365/ef.v60i1.308

[14.] Hidvégi P. - Bíró M. - Müller A. - Váczi P. (2017): Testnevelési program a munkahelyi egészségfejlesztésben, Acta Academiae Paedagogicae Agriensis Nova Series: Sectio Sport, 44, 115-138.

[15.] Hossain M. (2021): The effect of the Covid-19 on sharing economy activities. Journal of Cleaner Production, 280, 124782. DOI: $10.1016 /$ i.jclepro.2020.124782

[16.] Kós K. - Herpainé Lakó J. (2019): A család szerepe az egészségkárosító szokások tükrében. Acta Universitatis de Carolo Esżterhásy Nominatae: Sectio Sport, 46, 57-69. DOI: 10.33040/ActaUnivEszterhazySport.2019.1.57

[17.] Laoues-Czimbalmos N. - Bácsné Bába É. - Mező K. - Kőnig-Görögh D. - Müller A.: (2020a): Fogyatékos tanulók szabadidős preferenciarendszerének elemzése egy kutatás 
tükrében. International Journal of Engineering and Management Sciences / Müszaki és Menedzsment Tudományi Közlemények, 5(1), 98-115. DOI: 10.21791/IJEMS.2020.1.9

[18.] Laoues-Czimbalmos N. - Müller A. - Mező K. - Mercs E. - Molnár A. (2019): A környezeti nevelés és az egészséges életmód értékpreferenciáinak vizsgálata a "zöld" és "nem zöld" óvodába járó gyermekek szülei körében. Acta Carolus Robertus, 9(2), 89-109. DOI: 10.33032/acr.2019.9.2.89

[19.] Laoues-Czimbalmos N. - Pogácsás G. - Müller, A. (2020b): A család szerepe az egészséges életmód elemeinek kialakításában egy hátrányos helyzetűeket vizsgáló kutatás tükrében. In: Vargáné, Nagy Anikó (szerk.) Családi nevelés: Generációk közötti konfliktusok és megoldási stratégiák. Budapest: Forstag Nonprofit Közhasznú Kft, pp. 81-96.

[20.] Lengyel A. (2019): A mindfulness és liminalitás felértékelődése: spirituális elvonulási központok, a fenntartható jövő desztinációi? Turiz̧mus Bulletin, 19(1), pp. 14-24.

[21.] Lenténé P. A. - Tatár A. - Lente L. - Pucsok J. - Bíró M. - Hidvégi P. (2019): A sport és wellness elemek megjelenése az Észak- alföldi régió három-, négy- és ötcsillagos szállodáinak kínálatában. In: Bácsné, Bába Éva; Müller, Anetta (szerk.): "Mozgással az egészségért" A fizikeai aktivitás jelentösége a jövö munkavállalöinak egészségmegörzésében: Nemzetközi Konferencia és Workshop: Válogatott tanulmánykëtet $=$ "Movement for health" The importance of physical activity in health protection of future workers: International Conference and Workshop: Proceedings from the International Conference and Workshop. Debrecen: Debreceni Egyetem, pp. 204-215.

[22.] Lenténé- Puskás A. - Biró M. - Dobay B. - Pucsok J. M. (2018): A szabadidő sportolás kínálati elemeinek, és szolgáltatásainak vizsgálata Magyarország Észak-alföldi régiójának szállodáiban. Selye e-studies, 9(1), 13-21.

[23.] Lesser I. A. - Nienhuis C. P. (2020): The impact of COVID-19 on physical activity behavior and well-being of Canadians. International journal of environmental research and public health, 17(11), 3899. DOI: $\underline{10.3390 / \text { ijerph17113899 }}$

[24.] Molnár A. (2019): Fitnesz trendek az egészség szolgálatában. In: Bácsné, Bába Éva; Müller, Anetta (szerk.) "Mozgással az. egészségért" A firikai aktivitás jelentösége a jövö munkavállalóinak egészségmegörzésében: Nemzetkëzi Konferencia és W orkshop: Válogatott tanulmánykö̈tet = "Movement for health" The importance of physical activity in health protection of future workers: International Conference and Workshop: Proceedings from the International Conference and Workshop. Debrecen: Debreceni Egyetem, pp. 113-120.

[25.] Murtaza, Shah A. - Molnár E. - Szakács A. (2021): Digital Heroin - The Impact of Digital Gadgets on Developing Minds An Empirical Study on Growing Children of Lahore. Controller Info, 9(1), 55-58. DOI: 10.24387/CI.2021.1.10

[26.] Müller A. - Bácsné Bába É. (2018): Az egésæséges életmód és a sport kapcsolata. Létavértes: Létavértes SC '97 Egyesület.

[27.] Müller A. - Bácsné, Bába É. - Pfau, C. - Molnár A. - Laoues-Czimbalmos N. (2019a): Extrém sportfogyasztás vizsgálata egy kutatás tükrében. International Journal of Engineering and Management Sciences / Müszaki és Menedðsment Tudományi Közlemények, 4(3), 135-142. DOI: 10.21791/IJEMS.2019.3.13.

[28.] Müller A. - Bendíková E. - Herpainé Lakó J. - Bácsné Bába É. - Łubkowska W. - Mroczek B. (2019b): Survey of regular physical activity and socioeconomic status in Hungarian preschool children. Family Medicine and Primary Care Review, 21(3), 237-242. DOI: $10.5114 /$ fmpcr.2019.88382

[29.] Müller A. - Bíró M. - Hídvégi P. - Váczi P. - Plachy J - Juhász I. - Hajdú P. - Seres J. (2013): Fitnesz trendek a rekreációban. Acta Academiae Paedagogicae Agriensis Nova Series: Sectio Sport, 40, 25-34.

[30.] Müller A. - Szabó R. - Kerényi E. - Mosonyi A. (2009): Fürdőkutatás a Közép-dunántúli régióban. Acta Academiae Paedagogicae Agriensis Nova Series: Sectio Sport, 36, 77-87.

[31.] Péter V. (2015): Basketball. In: Melinda, Bíró (szerk.): Ball games: handball, football, volleyball, basketball. Eger: EKC Líceum Press, pp. 93-124. 
[32.] Poór J. (szerk.) - Dajnoki K. (szerk.) - Pató Gáborné Szűcs B. (szerk.) - Szabó Sz. (szerk.) (2021): Koronavirus-Válság: Kibivások és br válaszok: Elsó és második fázis összẹhasonlitása. Gödöllő: Magyar Agrár- és Élettudományi Egyetem.

[33.] Schuchat A. - Covid C. D. C. - Team R. (2020): Public health response to the initiation and spread of pandemic COVID-19 in the United States, February 24-April 21, 2020. Morbidity and mortality weekly Report, 69(18), 551-556. DOI: $10.15585 / \mathrm{mmwr} . \mathrm{mm} 6918 \mathrm{e} 2$

[34.] Simon I. Á. - Kajtár G. - Herpainé Lakó J. - Müller A. (2018): A fizikai aktivitás és a mentális egészség jelentősége a 60 év fölötti korosztály életében. Képzés és Gyakorlat: Training and Practice 16(1), 25-36. DOI:10.17165/TP.2018.1.3

[35.] Spence J. C. - Rhodes R. E. - McCurdy A. - Mangan A. - Hopkins D. - Mummery W. K. (2021): Determinants of physical activity among adults in the United Kingdom during the COVID- 19 pandemic: The DUK- COVID study. British journal of health psychology, 26(2), 588-605. DOI: $10.1111 /$ bjhp.12497

\section{Szerző}

Kinczel Antonia

Sport- és rekreációszervezés

II. Évfolyam

Debreceni Egyetem, GTK

antokincz@gmail.com 